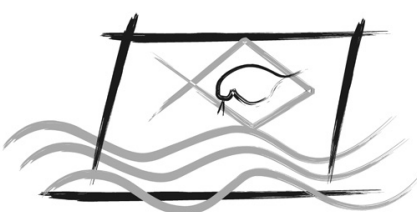

ECOTOX - BRASIL

\title{
Acute toxicity of Microcystis spp. (Cyanobacteria) bloom on Moina minuta (Cladocera) in a tropical reservoir, Northeastern Brazil
}

\author{
M.C.P. VIlar ${ }^{1 *}$, C.M.V. De AraúJo-CAStro ${ }^{2} \&$ A.N. Moura ${ }^{1 *}$ \\ 'Programa de Pós-graduação em Ecologia, Departamento de Biologia, Universidade Federal Rural de Pernambuco. Rua Dom Manoel de \\ Medeiros, s/n, CEP: 52171-900 - Recife, PE, Brasil. \\ ${ }^{2}$ Departamento de Morfologia e Fisiologia Animal, Universidade Federal Rural de Pernambuco. Rua Dom Manoel de Medeiros, s/n, CEP: \\ 52171-900 - Recife, PE, Brasil.
}

(Received May 7, 2014; Accept October 14, 2014)

\begin{abstract}
Worldwide cyanobacterial blooms have been registered, where harmful species dominance is associated to producing of toxic compounds (cyanotoxins) with adverse effects on several organisms. Acute toxicity of crude extracts from Microcystis bloom occurring in Mundaú reservoir was evaluated by bioassays with the neotropical Cladocera Moina minuta. Samples were taken in the reservoir during the rainy (April/2012) and dry season (September/2012). Cyanobacterial analyses were performed by identification on optical microscopy and direct counting using an inverted microscope. Bloom samples were frozen, lyophilized and re-suspended in deionized water for preparation of extracts. Tests with the cladoceran were carried out in test tubes with different concentrations of the crude extract, diluted in $10 \mathrm{~mL}$ reconstituted water. In both rainy and dry periods, densities of Microcystis spp. were above $15 \times 10^{3}$ ind $\mathrm{mL}^{-1}$. Microcystin concentrations in the extracts were $0.70( \pm 0,009)$ (rainy season) and $0.69( \pm 0,005)$ (dry season) $\mu \mathrm{g} \mathrm{g}^{-1}$. The $\mathrm{LC}_{50}(48 \mathrm{~h})$ of crude extract for both rainy and dry periods was $160(100-255)$ and $72(4-1113) \mathrm{mg} \mathrm{L}^{-1}$, respectively. These results indicated that extracts of Microcystis spp. were acutely toxic to M. minuta population with suggesting that such events represent potential toxicity to zooplankton.
\end{abstract}

Keywords: Eutrophication, microcystin, bioassay, zooplankton.

\section{INTRODUCTION}

Artificial eutrophication has been one of the main factors promoting cyanobacterial blooms in inland waters. The massive proliferation of these prokaryotic photosynthetic microorganisms, in most cases, is associated with production of toxins, which compromise the ecological stability of aquatic environments. Several genera are involved in the formation of blooms, especially Microcystis, a potential producer of microcystins, whose blooms form a dense algal biomass on the surface of the water body, consisting of colony aggregations, mainly in periods of high water residence time and of thermal stratification (Paerl, 1988).

The toxicity of Microcystis species has been widely reported in the literature, with records of animal (Chellapa et al., 2008; Nasri et al., 2008) and human poisoning, such as in Caruaru, state of Pernambuco (Northeastern Brazil), where 76 dialysis patients died after intravenous contamination by microcystin (Jochimsen et al., 1998).

Toxins synthesized by cyanobacteria can be characterized with regards to their biological activity, such as: hepatotoxins, cytotoxins (peptides and alkaloids), neurotoxins (alkaloids) and dermatotoxins (lipopolysaccharides, alkaloids and phenolic bislactones) (Chorus \& Bartram, 1999; Dittmann et al., 2013). The hepatotoxins are the most studied, especially the microcystins (MCs), which are cyclic heptapeptides distributed over 80 isoforms that vary according to the amino acids allocation in the side chains, methylations and double bonds, which provide different toxicity and polarity, being MC-LR the isoform of greatest toxicity, with an $\mathrm{LD}_{50}$ of $50 \mu \mathrm{g}$

*Corresponding author: Mauro Cesar Palmeira Vilar; e-mail: maurovilar@gmail.com; Ariadne do Nacimento Moura; e-mail: ariadne@db.ufrpe.br 
$\mathrm{kg}^{-1}$ in mice bioassays (Nidhi-Gupta et al., 2003; McElhiney \& Lawton, 2005; Dittmann \& Wiegand, 2006).

The availability of MCs in the water column can directly limit the survival of other individuals such as zooplankton due to potential toxicity. This has been discussed in the evolutionary perspective, regarding the role of each toxin as a chemical defense against herbivory (Lampert, 1981). Thus, these organisms can be excellent indicators of toxicity and bioaccumulation of cyanotoxins in aquatic systems (FerrãoFilho et al., 2009; Ferrão-Filho \& Kozlowsky-Suzuky, 2011).

Cladocerans are the most used group in ecotoxicological studies, especially the daphnid species: Daphnia similis Claus 1876, D. magna Straus, Ceriodaphnia silvestrii Daday and C. dubia Richard, which have been incorporated into protocols for toxicity testing in Brazil (ABNT, 2004; 2005). However, only $C$. silvestrii is a tropical species.

Investigations on the toxicity of cyanobacterial blooms in Brazilian reservoirs have been conducted with native species, such as C. silvestrii (Sotero-Santos et al., 2006; Okumura et al., 2007) which appear to be sensitive to the toxins. Species of the genus Moina Baird are also being used in toxicity experiments, due to their wide distribution in tropical waters, such as M. macropora Straus (Agrawal et al., 2001; AlvaMartínez et al., 2007) and M. micrura Kurz (Ferrão-Filho et al., 2014). These finds have consolidated the hypothesis of Ferrão-Filho et al. (2009) which emphasizes the importance of developing protocols with tropical cladocerans common to these water bodies.

Thus, the present study aimed to determine the potential of using the native cladoceran Moina minuta Hansen in assessing the effect of cyanobacterial blooms in a tropical reservoir with predominance of Microcystis species, through acute toxicity tests with crude extract of microcystin.

\section{MATERIALS AND METHODS}

\section{Sampling and qualitative and quantitative analysis}

The Mundaú Reservoir ( $\left.8^{\circ} 57^{\prime} 17^{\prime \prime} \mathrm{S}, 36^{\circ} 29^{\prime} 55^{\prime} \mathrm{W}\right)$ is an eutrophic and shallow water body, which is located in the city of Garanhuns, Pernambuco (Brazil); sited in the Mundaú River watershed at an altitude of $716 \mathrm{~m}$, with an accumulation capacity of $1.968 .000 \mathrm{~m}^{3}$ and water retention time occurring during the entire dry period (Moura et al., 2007; Dantas et al., 2008). The reservoir is intended for the public water supply, however currently receives part of the urban drainage and industrial effluent.

Samples of bloom were collected in April/2012 (rainy season) and September/2012 (dry season) using 20 $\mu \mathrm{m}$ mesh. These months showed a historical average rainfall (last 10 years) for the area of 97 and $62 \mathrm{~mm}$, respectively. Cyanobacteria of the genus Microcystis prevailed during the sampling period as recorded for other studies as BittencourtOliveira et al. $(2010 ; 2014)$.
Samples for taxonomic analysis were stored in polyethylene vials $(100 \mathrm{~mL})$ and preserved with $4 \%$ formalin. Cyanobacteria taxa were identified to the infrageneric level using specialized bibliography (Komárek \& Anagnostidis, 1989; 2000; 2005). For the quantitative analysis, subsurface samples were collected, stored in amber vials $(100 \mathrm{~mL})$ and preserved with $1 \%$ acetic Lugol solution. The taxa of cyanobacteria were expressed as a density (ind $\mathrm{mL}^{-1}$ ) using the method of Utermöhl (1958).

\section{Preparation of crude bloom extracts}

The bloom samples were centrifuged and lyophilized at $-80^{\circ} \mathrm{C}$, until complete dehydration to obtain dry biomass, which was stored at $-20^{\circ} \mathrm{C}$ until preparation of the extract. The lyophilized material was weighed on a precision balance, re-suspended in Milli-Q deionized water and homogenized in a vortex mixer for 2 minutes to obtain the extract at a concentration of $1000 \mathrm{mg} \mathrm{L}^{-1}$. The cells were then lysed in a Sonoplus HD 2070 sonicator for two 5-minute cycles at a frequency of $20 \mathrm{kHz}$, aiming to disrupt the cells and expose the intracellular content. Slides were prepared with debris to observe if all cells had been broken. The material was then centrifuged at 3,500 rpm for 10 minutes, which removed the supernatant, for preparation of different concentrations of crude extract to be tested, by dilution in reconstituted water (adapted from Okumura et al., 2007).

\section{Analysis of microcystin}

The content of microcystin in the extracts was quantified by ELISA. The results were expressed as total microcystin ( $\mu \mathrm{g}$ microcystin per $\mathrm{g}$ of dry biomass). The analyses were performed following the protocol of the kit for microcystin (Beacon Analytical Systems, Inc., Portland, ME, USA). The procedures were performed in triplicate in a microplate reader (ASYS Hitech GmbH, Nordstrasse 1714 Model A - 5301 Eugendorf, Austria).

\section{Cultivation and maintenance of cladocerans}

Clonal individuals of Moina minuta were obtained from cultures of the Laboratory of Aquatic Ecology at the Federal University of Paraiba. Cladocerans were maintained in reconstituted water under $\mathrm{pH} 7-8$, average temperature $25 \pm 2^{\circ} \mathrm{C}$ and $12 \mathrm{~h}$ photoperiod. Cladocerans were fed on a suspension of green algae: Desmodesmus quadricauda Turpin and Chlorella vulgaris Beyjerink [Beijerink] ad libitum.

\section{Acute toxicity tests}

Toxicity tests consisted of exposure of 10 neonates $(<24 \mathrm{~h})$ of $M$. minuta in test tubes containing $10 \mathrm{~mL}$ of different concentrations of crude extract, in triplicate. The concentrations used were: $0,62,125,250$ and $500 \mathrm{mg} \mathrm{L}^{-1}$ for the sample of the rainy season and $0,15,31,62$ and 125 $\mathrm{mg} \mathrm{L}^{-1}$ for the dry season. The crude extract was diluted in reconstituted water and test organisms were exposed without 
feeding under average temperature $25 \pm 2{ }^{\circ} \mathrm{C}$ and a photoperiod of $12 \mathrm{~h}$, for 48 hours. After the exposure period, the numbers of individuals killed at each concentration and in the control were recorded for calculation of $\mathrm{LC}_{50} 48 \mathrm{~h}$.

\section{Statistical analysis}

Data from the acute toxicity tests were analyzed using the Trimmed Spearman-Karber method for estimating median lethal concentration (Hamilton et al., 1977). To identify significant differences between the tested concentrations, the univariate analysis of variance (one-way ANOVA) was used, after examination of data normality and homoscedasticity of variances. If a difference was detected, the Dunnett test was used a posteriori. Statistical tests were carried out using SigmaPlot 11.0.

\section{RESULTS}

During the two sampling periods, the phytoplankton community showed predominance of the cyanobacteria Microcystis aeruginosa and M. panniformis, forming dense multispecies blooms, and co-occurring at densities of $59 \times 10^{3}$ and $14 \times 10^{2}$ ind $\mathrm{mL}^{-1}$ in the rainy season, and $96 \times 10^{2}$ and $56 \times 10^{2}$ ind $\mathrm{mL}^{-1}$ in the dry season, respectively. We also recorded the occurrence of the cyanobacteria Cylindrospermopsis raciborskii (Woloszynska) Seenaya \& Subba Raju, Geitlerinema amphibium (C. Agardh) Anagnostidis and Merismopedia tenuissima Lemmermann, which showed total densities of less than $66 \times 10^{2}$ ind $\mathrm{mL}^{-1}$ in both study periods.

Figure 1 shows the mortality of Moina minuta after $48 \mathrm{~h}$ exposure to various concentrations of crude extract of cyanobacterial bloom. Mortality was greater for the different periods in the higher concentration of crude extract analyzed. We observed a significant increase in the percentage of

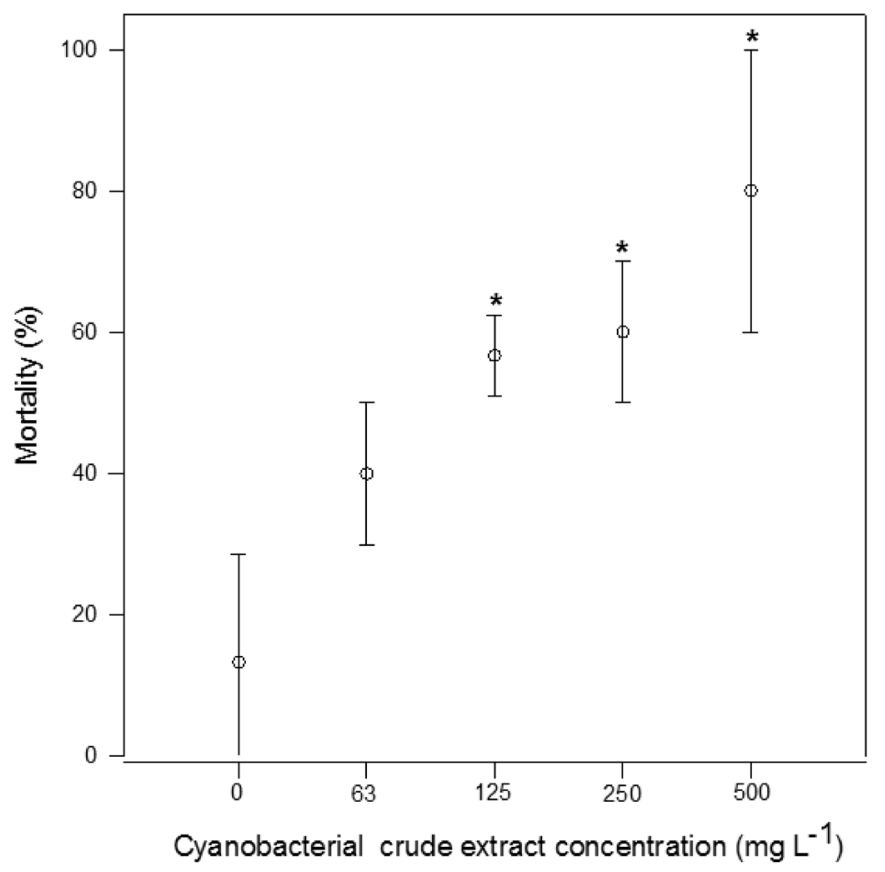

mortality with increased concentration of the extract in the rainy season $(\mathrm{F}=10.769, p<0.01)$ and dry season $(\mathrm{F}=5.18$, $p<0.05$ ), with the observed effect concentration (OEC) equal to or above $125 \mathrm{mg} \mathrm{L}^{-1}$ (Dunnett, $p<0.05$ ) and $62 \mathrm{mg} \mathrm{L}^{-1}$ (Dunnett, $p<0.05$ ) for these periods, respectively.

The results show that the content of microcystin in the bloom extract from Mundaú reservoir was similar in both rainy ad dry season, however there were differences in the $\mathrm{LC}_{50}(48 \mathrm{~h})$ to M. minuta (Table 1), with greater toxicity in the September/2012 (dry season) sample.

\section{DISCUSSION}

This record of prevalent and multispecies blooms of Microcystis is evidence of the high stage of eutrophication of the Mundaú Reservoir. Soares et al. (2013) suggest that the high flexibility of these taxa in adapting to seasonal environmental changes may have promoted an additional advantage for the increase of persistent blooms, particularly in tropical regions.

Studies in tropical eutrophic reservoirs have recorded the occurrence of multispecies algal blooms formed by potentially toxic cyanobacteria (Costa et al., 2006; Moura et al., 2011),

Table 1. Median lethal values $\left(\mathrm{LC}_{50}-48 \mathrm{~h}\right)$ and $95 \%$ confidence intervals (CI) estimated for Moina minuta and concentrations of microcystin with its standard deviation (SD) for the crude extracts tested. Values represented as dry weight (DW) and as microcystin (MC) content in crude extract.

\begin{tabular}{lcc}
\hline \multirow{2}{*}{ Sample } & $\mathrm{LC}_{50}-48 \mathrm{~h}(95 \% \mathrm{CI})$ & Microcystin concentration (SD) \\
\cline { 2 - 3 } & $\mathrm{mg} \mathrm{DW} \mathrm{L}-1$ & $\mu \mathrm{MC} \mathrm{g}^{-1}$ \\
$\begin{array}{l}\text { April/2012 } \\
\text { (rainy season) }\end{array}$ & $160(100-255)$ & $0.70( \pm 0.009)$ \\
\hline $\begin{array}{l}\text { September/2012 } \\
\text { (dry season) }\end{array}$ & $72(4-1104)$ & $0.69( \pm 0.005)$ \\
\hline
\end{tabular}

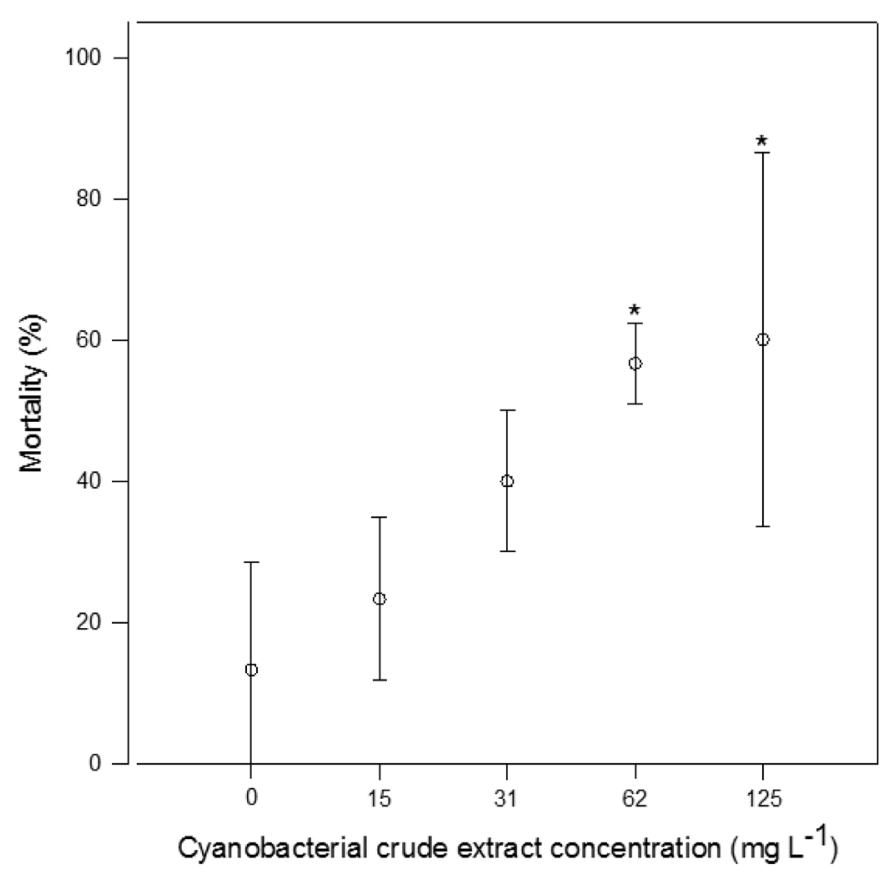


mainly in Northeastern Brazil where high densities of these microorganisms are a recurring feature in public water supply reservoirs (Moura et al., 2007; Chellappa et al., 2008; Dantas et al., 2010; Lira et al., 2011). Furthermore, there are frequent reports of cyanotoxins to the reservoir sampled, as BittencourtOliveira et al. (2010; 2014).

In this study, the $48 \mathrm{~h} \mathrm{LC}_{50}$ values to Moina minuta (160 and $72 \mathrm{mg} \mathrm{L}^{-1}$ ) are in agreement with those observed in previous studies as Sotero-Santos et al. $(2008 ; 2006)$ and Takenaka et al. (2007). Most have investigated sensibility of native cladocerans to cyanobacteria as Ferrão-Filho et al. (2014) that reported greater $48 \mathrm{~h} \mathrm{LC}_{50}$ values to M. micrura (413 and 853 $\mathrm{mg} \mathrm{L}^{-1}$ ) and Daphnia laevis (413 and $853 \mathrm{mg} \mathrm{L}^{-1}$ ) exposed to microcystin-producing cyanobacterial blooms, which was less sensitive in comparing to our findings. However, SoteroSantos et al. (2008) have pointed out that a cyanobacterial crude extract may contain others metabolites which can exert synergistic, additive or antagonistic effects.

Although most ecotoxicological studies have been performed with species of daphnids (Okumura et al., 2007; Ferrão-Filho et al., 2010), toxicity tests with Moina spp., especially with tropical species, have demonstrated the sensitivity of these organisms that enables them to be used as indicators of the toxic effects of cyanobacteria (Yasuno \& Sugaya, 1991; Ferrão-Filho et al., 2000; Agrawal et al., 2001). Furthermore, although there is a trend in the use of cladocerans in ecotoxicological tests, studies with other microcrustaceans, like the tanaidacea Kalliapseudes schubartii, have also showed the cyanobacterial toxicity (Montagnolli et al., 2004).

A difference in toxicity between the different extracts tested was observed, although similar concentrations of microcystin were recorded (Table 1). Other studies, as Takenaka et al. (2007), have reported an indirect relationship between the concentration of microcystins and the toxicity of the crude extracts of cyanobacteria to the cladocerans $C$. dubia and C. silvestrii.

Furthermore, sometimes cyanobacterial blooms can be composed by several cyanotoxin-producing species, which can result in a mixture of different bioactive compounds. Exposition experiments of D. magna to hepatotoxic and neurotoxic cyanobacterial extracts have shown additive and synergistic toxic effects on its feeding rate (Freitas et al., 2014).

Blooms in the same water body may vary in toxicity over a short period of time depending on the composition of toxic and non toxic strains (Yéprémian et al., 2007; Molica \& Azevedo, 2009). Znachor et al. (2006) recorded monthly changes on the qualitative and quantitative content of microcystin (MC-LR; - RR and-YR) in Microcystis spp. bloom samples of 18 reservoirs in the Czech Republic. The authors observed different concentrations of MC-LR among months. This dynamic on microcystin isoforms may produce different toxicity, as reported by Nidhi-Gupta et al. (2003) which studied the comparative toxicity of microcystin-LR, $\mathrm{RR}$ and $-\mathrm{YR}$ in mice, where the MC-LR was the most toxic.
Taking into consideration our findings regarding the toxicity of microcystin containing extract to $M$. minuta, as well as the possibility that high concentrations of extracellular cyanotoxins can be reached in the water body during bloom senescence, we can expect some negative effects of the toxin on aquatic ecosystems.

In conclusion, the data obtained in this acute toxicity test showed that M. minuta was sensitive to cell-bound microcystin released from bloom of Microcystis spp. sample, reinforcing the importance of using indigenous organisms for biomonitoring and predicting ecological impacts from cyanotoxins in tropical freshwater reservoirs.

\section{AKNOWLEDGEMENTS}

We would like to thank CNPq for scholarship, Laboratory of Biotechnology/CENAPesq/UFRPE (Center for Research Support/Federal Rural University of Pernambuco) for the samples processing, Laboratory of Aquatic Ecology from the Federal University of Paraiba, for the cladoceran clones and the anonymous reviewers for the comments on improving this paper.

\section{REFERENCES}

ABNT (Associação Brasileira de Normas Técnicas). 2004. Ecotoxicologia aquática - Toxicidade aguda - Método de ensaio com Daphnia spp (Crustacea, Cladocera), Norma ABNT-NBR 12713, Rio de Janeiro. 21p.

ABNT (Associação Brasileira de Normas Técnicas). 2005. Ecotoxicologia aquática - Toxicidade crônica - Método de ensaio com Ceriodaphnia spp (Crustacea, Cladocera), Norma ABNTNBR 13373, Rio de Janeiro. 15 p.

AGRAWAL, M.K., BAGCHI, D. \& BAGCHI, S.N. 2001. Acute inhibition of protease and suppression of growth in zooplankter, Moina macropora, by Microcystis blooms colleted in Central India. Hydrobiol., 464: 37-44. http://dx.doi. org/10.1023/A:1013946514556

ALVA-MARTÍNEZ, A.F., SARMA, S.S.S. \& NANDINI, S. 2007. Effect of mixed diets (cyanobacteria and green algae) on the population growth of the cladocerans Ceriodaphnia dubia and Moina macropora. Aquat. Ecol., 41(4): 579-585. http://dx.doi. org/10.1007/s10452-007-9115-1

BITTENCOURT-OLIVEIRA, M.C., PICCIN-SANTOS, V. \& GOUVÊA-BARROS, S. 2010. Microcystin-Producing Genotypes from Cyanobacteria in Brazilian Reservoirs. Environ. Toxicol., 27(8): 461 - 471. http://dx.doi.org/10.1002/tox.20659

BITTENCOURT-OLIVEIRA, M.C., PICCIN-SANTOS, V., MOURA, A.N., ARAGÃO-TAVARES, N.K.C. \& CORDEIROARAÚJO, M.K. 2014. Cyanobacteria, microcystins and cylindrospermopsin in public drinking supply reservoirs of Brazil. An. Acad. Bras. Ciênc., 86(1): 297 - 310. http://dx.doi. org/10.1590/0001-3765201302512

CHELlAPPA, N.T., CHELlAPPA, S.L. \& CHELlAPPA, S. 2008. Harmful Phytoplankton Blooms and Fish Mortality in a eutrophicated reservoir of Northeast Brazil. Braz. Arch. Biol. Techn., 51(4): 833-841. http://dx.doi.org/10.1590/S151689132008000400022

CHORUS, I. \& BARTRAM, J. 1999. Toxic Cyanobacteria in water: a guide to their public health consequences, monitoring and 
management. E and FN Spon, London. 400p.

COSTA, I.A.S., AZEVEDO, S.M.F.O., SENNA, P.A.C., BERNARDO, R.R., COSTA, S.M. \& CHELLAPPA, N.T. 2006 Occurrence of toxin-producing Cyanobacteria blooms in a Brazilian semi arid reservoir. Braz. J. Biol., 66(1B): 211 - 219. http://dx.doi.org/10.1590/S1519-69842006000200005

DANTAS, E.W., MOURA, A.N., BITTENCOURT-OLIVEIRA, M.C., ARRUDA-NETO, J.D.T. \& CAVALCANTI, A.D.C. 2008. Temporal variation of the phytoplankton community at short sampling intervals in the Mundaú reservoir, Northeastern Brazil. Acta Bot. Bras., 22(4): 970 - 982. http://dx.doi. org/10.1590/S0102-33062008000400008

DANTAS, E.W., BITTENCOURT-OLIVEIRA, M.C. \& MOURA, A.N. 2010. Spatial-temporal variation in coiled and straight morphotypes of Cylindrospermopsis raciborskii (Wolsz) Seenayya et Subba Raju (Cyanobacteria). Acta Bot. Bras., 24(2): 585-591. http://dx.doi.org/10.1590/S0102-33062010000200028

DITTMANN, E. \& WIEGAND, C. 2006. Cyanobacterial toxinsoccurrence, biosynthesis and impact on human affairs. Mol. Nutr. Food Res., 50: 7-17. http://dx.doi.org/10.1002/mnfr.200500162

DITTMANN, E., FEWER, D.P. \& NEILAN, B.A. 2013. Cyanobacterial toxins: biosynthetic routes and evolutionary roots. FEMS Microbiol. Rev., 37: 23-43. http://dx.doi. org/10.1111/1574-6976.12000

FERRÃO-FILHO, A.S., AZEVEDO, S.M.F.O. \& DEMOTT, W. 2000. Effects of toxic and non-toxic cyanobacteria on the life history of tropical and temperate cladocerans. Freshwat. Biol., 45: 1-19. http://dx.doi.org/10.1046/j.1365-2427.2000.00613.x

FERRÃO-FILHO, A.S., SOARES, M.C.S., MAGALHÃES, V.F. \& AZEVEDO, S.M.F.O. 2009. Biomonitoring of cyanotoxins in two tropical reservoirs by cladoceran toxicity bioassays. Ecotoxicol. Envion. Saf., 72: 479-489. http://dx.doi. org/10.1016/j.ecoenv.2008.02.002.

FERRÃO-FILHO, A.S., SOARES, M.C.S., MAGALHÃES, V.F. \& AZEVEDO, S.M.F.O. 2010. A rapid bioassay for detecting saxitoxins using a Daphnia acute toxicity test. Environ. Pollut., 158: 2084-2093. http://dx.doi.org/10.1016/j.envpol.2010.03.007

FERRÃO-FILHO, A.S. \& KOZLOWSKY-SUZUKI, B. 2011. Cyanotoxins: Bioaccumulation and Effects on Aquatic Animals. Mar. Drugs, 9(12): 2729-2772. http://dx.doi.org/10.3390/ md9122729

FERRÃO-FILHO, A.S., HERRERA, N.A. \& ECHEVERRI, L.F. 2014. Microcystin accumulation in cladocerans: First evidence of MC uptake from aqueous extracts of a natural bloom sample. Toxicon, 87: 26 - 31. http://dx.doi.org/10.1016/j. toxicon.2014.05.015

FREITAS, E.C., PINHEIRO, C., ROCHA, O. \& LOUREIRO, S. 2014. Can mixtures of cyanotoxins represent a risk to the zooplankton? The case study of Daphnia magna Straus exposed to hepatotoxic and neurotoxic cyanobacterial extracts. Harmful Algae, 31: 143 - 153. http://dx.doi.org/10.1016/j.hal.2013.11.004

HAMILTON, M.A., RUSSO, R.C. \& THURFTON, R.B. 1977. Trimmed Spearman-Karber methods for estimating median lethal concentration in toxicity bioassay. Environ. Sci. Technol., 11: 714-719. http://dx.doi.org/10.1021/es60130a004

JOCHIMSEN, E.M., CARMICHAEL, W.W., AN, J., CARDO, D.M., COOKSON, S.T., HOLMES, C.E.M., ANTUNES, B.C., MELO-FILHO, D.A., LYRA, T.M., BARRETO, V.S.T., AZEVEDO, S.M.F.O. \& JARVIS, W.R. 1998. Liver failure and death after exposure to microcystins at a hemodialysis center in Brazil. N. Engl. J. Med., 338(13): 873-878. http:/dx.doi. org/10.1056/NEJM199803263381304

KOMÁREK, J. \& ANAGNOSTIDIS, E.K. 1989. Modern approach to the classification system of Cyanophytes 4: Nostocales. Algol.
Stud., 56: 247-345.

KOMÁREK, J. \& ANAGNOSTIDIS, K. 2000. Cyanoprokaryota: Chroococcales. In: Ettl, H., Gärtner, G., Heynig. H. \& Mollenhauer, D. (ed). Süßwasserflora von Mitteleuropa. Gustav Fischer, Stuttgart: Germany. pp 1-658.

KOMÁREK, J. \& ANAGNOSTIDIS, K. 2005. Süßwasserflora von Mitteleuropa. T2: Oscillatoriales. Spektrum Akademischer Verlag, Elsevier GmbH, München, 759p.

LAMPERT, W. 1981. Toxicity of blue-green Microcystis aeruginosa: effective defense mechanism against grazing pressure by Daphnia. Verh. Internat. Verein. Theor. Angew. Limnol., 21: 1436-1440.

LIRA, G.A.S.T., ARAÚJO, E.L., BITTENCOURT-OLIVEIRA, M.C. \& MOURA, A.N. 2011. Phytoplankton abundance, dominance and coexistence in an eutrophic reservoir in the state of Pernambuco, Northeast Brazil. An. Acad. Bras. Ciênc., 83(4): 1313-1326. http://dx.doi.org/10.1590/S000137652011000400018

MC ELHINEY, J. \& LAWTON, L.A. 2005. Detection of the cyanobacterial hepatotoxins microcystins. Toxicol. Appl. Pharm., 203: 219-230. http://dx.doi.org/10.1016/j.taap.2004.06.002

MOLICA, R. \& AZEVEDO, S. 2009. Ecofisiologia de Cianobactérias Produtoras de Cianotoxinas. Oecol. Bras., 13(2): 229-246.

MONTAGNOLLI, W., ZAMBONI, A., LUVIZOTTO-SANTOS, R. \& YUNES, J.S. 2004. Acute effects of Microcystis aeruginosa from the Patos lagoon estuary, Southern Brazil, on the microcrustacean Kalliapseudes schubartii (Crustacea: Tanaidacea). Arch. Environ. Con. Tox., 46: 463-469. http:// dx.doi.org/10.1007/s00244-003-2304-6

MOURA, A.N., BITTENCOURT-OLIVEIRA, M.C., DANTAS, E.W. \& ARRUDA-NETO, J.D.T. 2007. Phytoplanktonic associations: a tool to understanding dominance events in a tropical Brazilian reservoir. Acta Bot. Bras., 21(3): 641-648. http://dx.doi.org/10.1590/S0102-33062007000300011

MOURA, A.N., DANTAS, E.W., OLIVEIRA, H.S.B. \& BITTENCOURT-OLIVEIRA, M.C. 2011. Vertical and temporal dynamics of cyanobacteria in the Carpina potable water reservoir in northeastern Brazil. Braz. J. Biol., 71(2): 1-9. http://dx.doi. org/10.1590/S1519-69842011000300015

NARSRI, H., EL-HERRY, S. \& BOUAÏCHA, N. 2008. First reported case of turtle deaths during a toxic Microcystis spp. bloom in Lake Oubeira, Algeria. Ecotoxicol. Envion. Saf., 71: 535-544. http://dx.doi.org/10.1016/j.ecoenv.2007.12.009

NIDHI-GUPTA, S.C., PANT, R., VIJAYARAGHAVAN, P.V. \& LAKSHMANA, R. 2003. Comparative toxicity evaluation of cyanobacterial cyclic peptide toxin microcystin variants (LR, RR, YR) in mice. Toxicology, 188: 285 - 296. http://dx.doi. org/10.1016/S0300-483X(03)00112-4

OKUMURA, D.T., SOTERO-SANTOS, R.B., TAKENAKA, R.A. \& ROCHA, O. 2007. Evaluation of cyanobacteria toxicity in tropical reservoirs using crude extracts bioassay with cladocerans. Ecotoxicology, 16: 263-270. http://dx.doi.org/10.1007/s10646006-0126-9

PAERL, H.W. 1988. Growth and reproductive strategies of freshwater blue-green algae (Cyanobacteria). In: Sandgren, C.D. (ed) Growth and Reproductive Strategies of Freshwater Phytoplankton, Cambridge University Press. pp. 261-315.

SOARES, M.C.S., LÜRLING, M. \& HUSZAR, V. 2013. Growth and temperature-related phenotypic plasticity in the cyanobacterium Cylindrospermopsis raciborskii. Phycol. Res., 61: 61 - 67. http:// dx.doi.org/10.1111/pre.12001

SOTERO-SANTOS, R.B., SILVA, C.R.S.E., VERANI, N.F., NONAKA, K.O. \& ROCHA, O. 2006. Toxicity of a cyanobacteria Bloom in Barra Bonita Reservoir (Middle Tietê 
River, São Paulo, Brazil). Ecotoxicol. Envion. Saf., 64:163-170. http://dx.doi.org/10.1016/j.ecoenv.2005.03.011

SOTERO-SANTOS, R.B., CARVALHO, E.G., DELLAMANOOLIVEIRA, M.J. \& ROCHA, O. 2008. Occurrence and toxicity of an Anabaena bloom in a tropical reservoir (Southeast Brazil). Harmful Algae, 7: 590-598. http://dx.doi.org/10.1016/j. hal.2007.12.017

TAKENAKA, R.A., DELLAMANO-OLIVEIRA, M.J. \& ROCHA, O. 2007. Toxicidade de Extratos de Florações de Cianobactérias de Reservatórios do Rio Tietê, SP, aos Dafinídeos Ceriodaphnia dubia e Ceriodaphnia silvestrii (Cladocera, Crustacea). J. Braz. Soc. Ecotoxicol., 2(2): 147-156. http://dx.doi.org/10.5132/ jbse.2007.02.007

UTERMÖHL, H. 1958. Zur Vervollkommnung der quantitativen Phytoplankton-Methodik. Verh. Internat. Verein. Theor. Angew.
Limnol., 9: 1-38.

YASUNO, M. \& SUGAYA, Y. 1991. Toxicities of Microcystis viridis and the isolated hepatotoxic polypeptides on cladocerans. Verh. Internat. Verein Limnol., 24: 2622-2626.

YÉPRÉMIAN, C., GUGGER, M.F., BRIAND, E., CATHERINE, A., GERGER, C., QUIBLIER, C. \& BERNARD, C. 2007. Microcystin ecotypes in a perennial Planktothrix agardhii bloom. Water Res., 41: 4446-4456. http://dx.doi.org/10.1016/j. watres.2007.06.028

ZNACHOR, P., JURCZAK, T., KOMÁRKOVÁ, J., JEZBEROVÁ, J., MANKIEWICZ, J., KASTOVSKÁ, K. \& ZAPOMELOVÁ, E. 2006. Summer changes in Cyanobacterial bloom composition and microcystin concentration in Eutrophic Czech Reservoirs. Environ. Toxicol., 21(3): 236 - 243. http://dx.doi.org/10.1002/ tox. 20176 . 